\title{
Aboveground tree biomass of Araucaria araucana in southern Chile: measurements and multi-objective optimization of biomass models
}

\author{
Erico Kutchartt ${ }^{(1)}$, \\ Jorge Gayoso ${ }^{(2)}$, \\ Francesco Pirotti ${ }^{(1)}$, \\ Álvaro Bucarey ${ }^{(2)}$, \\ Javier Guerra ${ }^{(3)}$, \\ Jaime Hernández ${ }^{(4)}$, \\ Patricio Corvalán ${ }^{(4)}$, \\ Karel Drápela ${ }^{(5)}$, \\ Mark Olson ${ }^{(6)}$, \\ Martin Zwanzig ${ }^{(7)}$
}

$\square$ (1) Department of Land, Environment, Agriculture and Forestry (TESAF), University of Padova, v. dell'Università 16, I-35020 Legnaro, PD (Italy); (2) Instituto de Bosques y Sociedad (IBOS), Universidad Austral de Chile, Campus Isla Teja, Valdivia (Chile); (3) Campo Digital GIS and Remote Sensing, Sarmiento 1767, Osorno (Chile); (4) Departamento de Gestión Forestal y su Medio Ambiente, Universidad de Chile, Santa Rosa, 11315 La Pintana, Santiago (Chile); (5) Department of Forest Management and Applied Geoinformatics (FFWT), Mendel University in Brno, Zemedelská 3, 61300 Brno (Czech Republic); (6) Instituto de Biología, Universidad Nacional Autónoma de México, Tercer Circuito s/n de Ciudad Universitaria, Ciudad de México 04510 (México); (7) Department of Forest Sciences, Institute of Forest Growth and Forest Computer Sciences, Technische Universität Dresden, Pienner Str. 8, D-01737 Tharandt (Germany)

@ Erico Kutchartt

(erico.kutchartt@phd.unipd.it)

Received: May 05, 2020 - Accepted: Dec 10, 2020

Citation: Kutchartt E, Gayoso J, Pirotti F, Bucarey Á, Guerra J, Hernández J, Corvalán P, Drápela K, Olson M, Zwanzig M (2021). Aboveground tree biomass of Araucaria araucana in southern Chile: measurements and multi-objective optimization of biomass models. iForest 14: 61-70. - doi: 10.3832/ifor3492-013 [online 2021-02-09]

Communicated by: Alessio Collalti

Estimating carbon stocks in wooded systems is crucial to quantify national greenhouse gas balance estimates. However, inaccurate estimates are likely due to the divergent architecture of many species. The monkey puzzle tree Araucaria araucana, with its umbrella-like architecture is a vivid example. This species, often found in monodominant stands at high elevations, is the greatest carbon reservoir in the landscape, hence estimating its carbon storage is crucial. To provide the necessary basis for these estimations, we documented the variation in basic density and moisture content along the stem profile, identified the most suitable biomass estimation models, and quantified biomass allocation for three age ranges. We measured, felled, weighed, and separated trees into three categories: stem wood, stem bark, and foliage (branches + scaly leaves). The log-linear form of the simple allometric equation $Y=a X^{\mathrm{b}}$, based on diameter at breast height as the explanatory variable, covered a large part of the variation and showed good cross-validation performance $(>0.96)$. Models using more covariates achieved lower absolute errors, but the estimation of the additional model parameters was associated with greater uncertainty. A multi-objective model comparison revealed that the best additional covariate to further improve biomass estimation was total tree height. The mean absolute percentage error was $9.8 \%$ for the total aboveground biomass, $8 \%$ for stem wood, $12 \%$ for stem bark and $24 \%$ for foliage. Changes in biomass distribution among tree components were related to age. For older trees, there was a relative increase in stem wood, a decreased proportion of foliage, but no change in stem bark. The proportion of stem bark biomass is similar to that of Araucaria angustifolia, but higher than in other conifers and most trees in general. Our results provide key properties for $A$. araucana and general guidance for the selection of easily-measurable variables allowing for excellent predictive power for local biomass estimation.

Keywords: Monkey Puzzle Tree, Carbon Stocks, Forest Modelling, Multicriteria Optimization, Allometry

\section{Introduction}

Accurate estimates of aboveground biomass are essential for a wide range of studies including carbon and nutrient cycling and global climate change. Aboveground biomass is often inferred via allometric equations or biomass estimation models (BEM) which relate biomass to more readily measurable attributes such as diameter at breast height, total height or crown dimensions (Cutini et al. 2013). Many species have relatively similar habits, thus there is some justification for applying BEMs developed for one species to similar ones (Fayolle et al. 2013). However, trees with uncommon habits can be significant contributors to landscape carbon storage, and the lack of appropriate BEMs stands in the way of generating trustworthy estimates for these species. With its umbrella-like appearance (Fig. S1 in Supplementary material), the monkey puzzle tree (Araucaria araucana [Mol.] K. Koch.) is a vivid example. This species is mainly found in large areas of highland woodland along a large latitudinal gradient spanning Chile and Argentina. With its abundance and often massive size, $A$. araucana is a major or in most cases the main contributor of forest biomass. The monkey puzzle tree can reach a height of $50 \mathrm{~m}$ and a $\mathrm{DBH}$ of 250 $\mathrm{cm}$ (Aagesen 2004) and cover more than 400,000 ha between Chile and Argentina (Donoso et al. 2014). Although it is considered a sacred tree by the Pewenche people (Aagesen 2004), the species is intensively used economically for its large edible seeds, which affects its regeneration (Aagesen 1998). The monkey puzzle tree has been listed in CITES Appendix I since 2011. It is also listed as an endangered species in the IUCN Red Data list (Premoli et al. 2013). Araucaria araucana forests are constantly beset by intentional forest fires, high pressure by livestock, and the introduction of exotic species. Accurate estimation of the monkey puzzle tree's biomass is imperative considering its important landscape carbon sequestration and the threats it faces. The inclusion of $A$. araucana in the list of species that can be assessed with tools for accurate biomass estimation conforms to the UNFCCC stipulation to quantify and report the carbon sequestration in all forest eco- 
systems at country level (Beets \& Garrett 2018).

Identifying accurate and easily applicable BEMs for the monkey puzzle tree is relevant for various reasons. In addition to quantification of carbon stocks for national greenhouse gas balance estimates, BEMs provide access to important information such as rigorous documentation of forest structure and the measurements of indicators of site productivity (Beets et al. 2012). BEMs are mostly implemented in the form of local and general models. Local equations are based on covariates such as DBH (diameter breast height), HT (total height), plus a response variable (e.g., volume or biomass), and apply to local site conditions. General equations are based on two or more covariates at the stand level (Payandeh 1981) and involve wider geographical zones. The inclusion of a second predictor including $\mathrm{HT}$ as an explanatory variable has been shown to improve the precision of biomass estimates (Samuelson et al. 2014). Likewise, the inclusion of additional variables (e.g., crown length) in such mod els could provide more accurate predic tions, mainly for branches and leaves (González-Benecke et al. 2014).

The determination of dry biomass and carbon storage depends on accurate measurement of basic density and moisture content. Wet biomass, which includes a variable amount of moisture, can only be determined by field measurements. Some studies found variation in basic density and moisture content from the stump to the top in conifers (Antony et al. 2012). Such information is crucial to accurately calculate dry weight biomass and carbon stocks. These data are especially important when these values are not constant for different tree components.

With these considerations in mind, we developed BEMs for $A$. araucana. Our proce dures included basic density and moisture content along the stem, while assessing the predictive ability of models with different sets of predictor variables. We also sought to assess whether the inclusion of additional variables such as tree height and crown dimensions can substantially improve biomass estimation models (González-Benecke et al. 2014).

The aims of this study were: (i) to document the variation in basic density and moisture content along the whole tree, including differences between tree components in A. Araucana; (ii) to select a set of suitable site- and species- specific biomass models to estimate dry weight of aboveground biomass and models for tree components, such as stem wood, stem bark, and foliage (branches + leaves); (iii) to analyse how biomass is distributed among the components of A. araucana trees of different ages.

\section{Material and methods}

The study was conducted at La Fusta Forest on the lower slopes of the Andes mountain range in southern Chile $\left(38^{\circ} 34^{\prime}\right.$ $28^{\prime \prime} \mathrm{S}, 71^{\circ} 26^{\prime} 22^{\prime \prime} \mathrm{W}$ ) about $15 \mathrm{~km}$ south of the town of Lonquimay in La Araucania Region (Fig. 1). The topography of the study area is relatively uniform, ranging from 1288 to $1376 \mathrm{~m}$ a.s.l. The climate is cool and moist, with a mean annual precipitation of $1457 \mathrm{~mm}$, a mean minimum temperature of $-1.6{ }^{\circ} \mathrm{C}$ (July) and a mean maximum temperature of $25.0^{\circ} \mathrm{C}$ (February - AGRIMED 2017). The soils are derived from volcanic rock and are characterised by moderate to deep soil depth $(15-180 \mathrm{~cm})$, medium to fine soil texture with rapid to moderate drainage, acid $\mathrm{pH}$ (5.5) and low nutrient levels (Donoso 2006).

\section{Species description}

Araucaria araucana is an endemic gymnosperm tree of the temperate forests of southern Chile and Argentina, growing in the Andes and Coastal Ranges. The trunk is cylindrical, the bark is thick and fissured

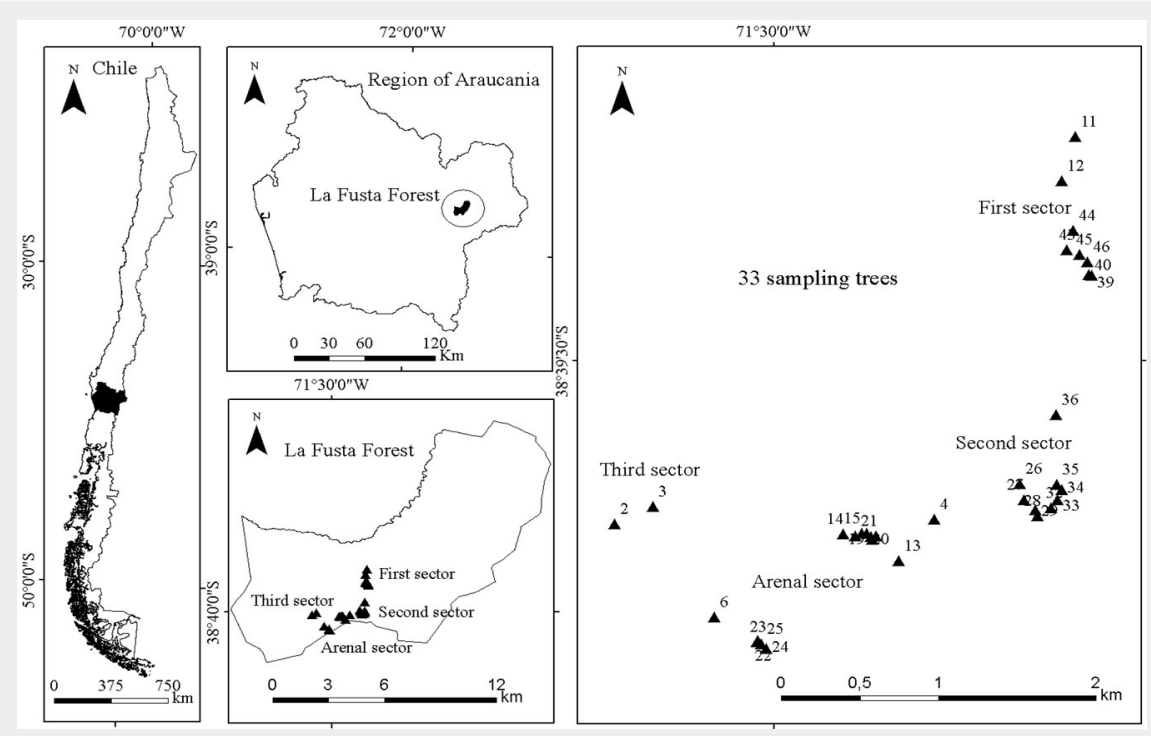

Fig. 1 - Study area: La Fusta forest in the Araucania Region, southern Chile. and can reach $20 \mathrm{~cm}$ in thickness, and trees can reach an age of 1300 years (Aagesen 2004). The coriaceous, scale-like leaves are triangular and 3-4 cm long (Donoso 2006). Araucaria araucana grows in association with Nothofagus species, such as Nothofagus antarctica (Forst.) Oerst., Nothofagus pumilio (Poepp. et Endl.) Krasser, Nothofagus obliqua (Mirb.) Bl., Nothofagus dombeyi (Mirb.) Bl., and Nothofagus alpina (Poepp. et Endl.) Oerst. (Schmidt 1977). With regard to the habit, trees are pyramidal when young, growing into large trees with most of the branches clustered near the trunk tip, with a wide, flattened, umbrella-like crown. This habit is mostly found in a few other species of Araucaria, but essentially nonexistent in other forest trees, underscoring the need for species-specific biomass estimation models.

\section{Fieldwork}

We carried out fieldwork in the spring of 2012 (Gayoso 2013). The selected trees covered the full range of sizes at the study site, including a DBH range from 10.0-126.4 $\mathrm{cm}$. Thirty-three trees were selected for destructive sampling. Trees were felled at 0.3 $\mathrm{m}$ height, cut into sections at $1 \mathrm{~m}$ intervals and weighed in the field using a digital scale with a two-ton capacity. Before harvesting the following data were recorded: diameter at stump height (DSH), diameter at breast height (DBH) and crown diameter $(\mathrm{CD})$, while crown length $(\mathrm{CL})$ and total height (HT) were measured on the ground after felling (Tab. 1).

Perpendicular crown diameter projected to the ground were measured with a tapemeasure while trees were still standing. Samples to determine basic density and moisture content were taken at DSH (0.3 $\mathrm{m}), 1.3 \mathrm{~m}(\mathrm{DBH})$, half of the total height and at the crown insertion (Fig. S1 in Supplementary material). In total 528 samples were gathered to trace the variation in basic density and moisture content along the stem profiles. In addition, three samples of foliage were taken from each tree, with the samples selected being less than $5 \mathrm{~cm}$ in diameter and gathered randomly from the crown (Fig. S2 in Supplementary material).

The allocation of biomass in the stem between wood and bark was documented by measuring stem diameter and bark thickness at $1-\mathrm{m}$ intervals along the stem with millimetre callipers. The volumes were calculated using the Smalian cubing approach (eqn. 1), modelling trunk shape as a truncated cone (Goulding 1979). The volume with and without bark was also calculated. The volume of bark and wood was multiplied by the specific basic density $\left(\mathrm{Mg} \mathrm{m}^{-3}\right)$ of each tree to obtain dry biomass distributed between both components (Kizha \& Han 2016 - eqn. 1):

$$
V=\frac{\pi}{4} \sum_{i=1}^{n} \frac{\left(d_{1}{ }^{2}+d_{2}{ }^{2}\right)}{2} \cdot l
$$

where $V$ is the volume of the $\log \left(\mathrm{m}^{3}\right), d_{1}$ is 
the basal diameter $(m), d_{2}$ is the apical diameter $(\mathrm{m})$, and $l$ is the length of each log (m).

The basic density was determined following ISO-13061-2 (2014) by immersion of saturated samples and measurement of water displacement. The samples for wood and bark components were arranged in different stem positions. Because of the large size of wood disks and wedges, cookies from different radial stem positions (pith, heartwood, sapwood) were employed as samples for wood basic density for each vertical stem position. The wood and bark samples were later dried at $105 \pm 2{ }^{\circ} \mathrm{C}$ and foliage samples at $70 \pm 2{ }^{\circ} \mathrm{C}$ until constant mass, which took about 48 hours. Once constant mass was reached, the dry mass was divided by the wet volume, and the wood density of each tree stem section assessed by averaging the density calculated from the respective cookies. The total basic density (BD) of a tree stem (wood or bark) was calculated as a weighted average, which included the volume of each tree stem section as a weighting factor (eqn. 2). The density of foliage was estimated using the same method of saturation and water displacement and was repeated three times.

$$
B D=\sum\left(W_{i} \cdot X_{i}\right)
$$

where $i$ is the stem position ( $i=$ STUMP, $\mathrm{DBH}, \mathrm{HALF},(\mathrm{ROWN}), \mathrm{W}_{\mathrm{i}}$ is the weighing by volume wood or bark fraction, and $X_{i}$ is the basic density or the moisture content.

Moisture content was determined using ISO-13061-1 (2014). In this method, the water content (difference between wet weight determined by a balance in situ and dry weight using a ventilated oven at $105 \pm$ $2{ }^{\circ} \mathrm{C}$ ) is computed as a percentage of the dry weight. At the same time, we determined the dry/wet ratio. The total moisture content per tree was calculated with eqn. 2 and was again repeated three times to estimate moisture content in foliage.

We chose to weigh branches with leaves on them, rather than separating the leaves from the branches. This is because the leaves are extremely long-lived in this species, and because they are scale-like with broad bases clothing the twigs, removing the fresh leaves also removes the cortical area and often the secondary phloem. As a result, weighing the twigs with leaves intact provides a better picture of their carbon content as well as providing greater accuracy (Fig. S2 in Supplementary material).

The age of all felled trees was conventionally determined by counting growth rings at breast height $(1.3 \mathrm{~m})$, where the samples did not have rotten tissues into the pith. A stereoscopic lens $5 \times$ was used for the larger diameter samples and a binocular Zeiss $10 \times$ for the smaller ones.

\section{Statistical tests}

To compare mean values in basic density

Tab. 1 - Attributes of the 33 Araucaria araucana trees sampled. (SD): standard deviation; (CV): coefficient of variation; (DBH): diameter at breast height; (HT): total height; $(C L)$ : crown length; $(C D)$ : crown diameter; $(W)$ : wood; $(B)$ : bark; $(F)$ : foliage; (TAGB): total aboveground biomass.

\begin{tabular}{|lcrrrrr}
\hline Attribute & Unit & Mean & \multicolumn{1}{c}{ SD } & CV (\%) & Minimum & Maximum \\
\hline DBH & $\mathrm{cm}$ & 51.8 & 33.5 & 64.8 & 10.0 & 126.4 \\
\hline AGE & - & 244.5 & 168.4 & 68.9 & 39.0 & 662.0 \\
\hline HT & $\mathrm{m}$ & 13.6 & 7.5 & 54.8 & 3.2 & 29.5 \\
\hline $\mathrm{CL}$ & $\mathrm{m}$ & 5.7 & 2.7 & 48.2 & 1.7 & 12.5 \\
\hline $\mathrm{CD}$ & $\mathrm{m}$ & 6.1 & 3.4 & 55.4 & 1.8 & 14.4 \\
\hline $\mathrm{W}$ & $\mathrm{kg}$ & 1205.8 & 1674.9 & 138.8 & 6.9 & 6296.1 \\
\hline B & $\mathrm{kg}$ & 320.8 & 467.5 & 145.7 & 2.7 & 1863.1 \\
\hline F & $\mathrm{kg}$ & 785.5 & 1020.0 & 129.8 & 12.5 & 4212.2 \\
\hline TAGB & $\mathrm{kg}$ & 2312.3 & 3113.1 & 134.6 & 22.5 & 12371.5 \\
\hline
\end{tabular}

and moisture content among tree components, a one factorial analysis of variance (one-way ANOVA) was used along with the post-hoc Tukey HSD test for multiple comparisons.

\section{Biomass calculation of tree components} With regard to stem wood and stem bark, the volume to dry mass was transformed using the specific basic density for wood and bark. With regard to foliage, the dry mass was computed by multiplying fresh biomass by a dry/wet weight ratio. Subsequently, the dry biomass was calculated in kilograms for each component, including stem wood, stem bark, and foliage. Finally, the total aboveground biomass was determined as the sum of the components. Fig. S3 (Supplementary material) shows the relationship across individuals between the dry biomass of each component and DBH.

\section{Biomass estimation models and multi-} objective optimization

The data gathered were used to assess how total aboveground biomass and the biomass of stem wood, stem bark, and foliage of $A$. araucana can be predicted by biomass models representing typical allometric equations (simple bivariate powerlaw functions) and local models with multiple predictors. We tested a total of 300 models, including 75 different covariate functions for each response variable (TAGB: total aboveground biomass; W: wood; B: bark; F: foliage). These included simple and multiple linear regression and functions with and without logarithmic transformation of the response and quadratic or logarithmic terms as well as interactions between covariates, all fitted by ordinary least squares. While homoscedasticity of residuals can be achieved by logtransformation and has been verified for all resulting best models, some of the other models performed poorly due to problems with variance inflation that occur if neither such a linearization nor an estimation with weighted least-squares regression is applied. DBH, HT, CL and CD were used as predictors. Other explanatory variables such as DSH, basal area, age, and wood density were omitted because their inclusion either did not improve the accuracy of biomass estimation in preliminary analysis or they were difficult to measure in the field or by remote sensing. Linear regression models were employed because they are well known and provide readily interpretable predictions regarding the ways that the response variable (biomass) is affected by covariates (explanatory variables). They can be used for prediction and can sometimes outperform more complicated nonlinear models in situations with a small number of observations (Hastie et al. 2017).

To assess the performance of local models, calculations for three different types of objectives were done. Firstly, general goodness-of-fit characteristics such as the coefficient of determination ( $R^{2}-$ eqn. 3$)$, the root mean square error (RMSE - eqn. 4), the percentage relative standard error (PRSE - eqn. 5), the mean absolute error (MAE - eqn. 6), and the mean absolute percentage error (MAPE - eqn. 7) were calculated. Secondly, K-fold cross-validation using the "train" function from the R package "caret" was repeated (Kuhn 2020) to see how well the models predicted new data, which here refers to a part of the data to which the models had not been fitted. For this procedure, all 33 observations were randomly divided into $K=7$ roughly equal-sized groups. The models were fitted to the data including six out of seven groups, which equated to around 28 observations, and evaluated how well they predicted the data of the remaining group (the "test data"). The test data represented around 5 observations or $15 \%$ of the data. This procedure was repeated 20 times for each model, resulting in estimates of goodness-of-fit such as $\mathrm{R}^{2}$, RMSE, and MAE, and their respective mean estimation errors. Although these measures of cross-validation performance and general goodness-of-fit can be used to select models that minimise the prediction error in 
various means, the fitted parameter values of the models might not be reliable estimates. The third objective is the identifiability of model parameters, which is indicated by the PRSE (\%) of the model parameters (eqn. 5), an important but sometimes neglected measure of model reliability or uncertainty (Sileshi 2014).

$$
\begin{aligned}
& R^{2}=1-\frac{\sum_{i=1}^{n}\left(y_{i}-\hat{y}_{i}\right)^{2}}{\sum_{i=1}^{n}\left(y_{i}-\bar{y}_{i}\right)^{2}} \\
& R M S E=\sqrt{\frac{1}{n} \sum_{i=1}^{n}\left(y_{i}-\hat{y}_{i}\right)^{2}} \\
& \text { PRSE }=100 \cdot \frac{S E(P)}{P} \\
& M A E=\sum_{i=1}^{n} \frac{\left|y_{i}-\hat{y}_{i}\right|}{n} \\
& \text { MAPE }=\frac{100}{n} \sum \frac{\left|\hat{y}_{i}-y_{i}\right|}{y_{i}}
\end{aligned}
$$

where $y_{i}$ is the observed value, $\hat{y}_{i}$ is the predicted value, $\bar{y}_{i}$ is the mean value, $n$ is the number of observations, $P$ is the parameter estimates and $S E(P)$ is the parameter standard error.

Finally, multi-objective optimization was used to identify the 75 equations (covariate functions) that best predicted biomass estimates, e.g., total aboveground biomass and the biomass of stem wood, stem bark, and foliage simultaneously. For this, MAPE was used to evaluate objective one, i.e., the general goodness-of-fit. The $\mathrm{R}^{2}$ of the repeated $K$-fold cross-validation was used to evaluate objective two, i.e., the ability to predict new data. Because models differed in their number of model parameters, the maximum of a model's PRSE of model parameters was used for objective three, i.e., calculating the robustness of model parameters. While MAPE and PRSE should be minimised, $R^{2}$ should be maximised for all response variables simultaneously. Since these estimates can only be directly com- pared between models predicting the same response variable, their values have been standardized for each response. For $\mathrm{R}^{2}$ this was done using the inverted values, such that the optimisation referred to the minimum for all quality criteria. The performance of each of the 75 equations was ultimately evaluated using the sum of the standardised performance measures that each of them showed for each response variable (TAGB, W, B, F). In this way, we ranked the performance of all equations. The following list shows the top five (eqn. 8 to eqn. 12), which are proposed as the most appropriate biomass estimation models for $A$. araucana:

$$
\begin{aligned}
& y=D B H^{\beta_{1}} e^{\beta_{0}} \\
& y=D B H^{\beta_{1}} e^{\beta_{0}+\beta_{2} H T} \\
& y=D B H^{\beta_{1}} e^{\beta_{0}+\beta_{2} C L} \\
& y=D B H^{\beta_{1}} e^{\beta_{0}+\beta_{2} H T+\beta_{3} C L} \\
& y=D B H^{\beta_{1}} e^{\beta_{0}+\beta_{2} C L+\beta_{3} C D}
\end{aligned}
$$

where $y$ is the response variable, $\beta_{0}, \beta_{1}, \beta_{2}$ and $\beta_{3}$ are model parameters estimated by ordinary least squares, $\mathrm{DBH}$ is the diameter breast height, $H T$ is the total height, $C L$ is the crown length, and $C D$ is the crown diameter.

\section{Analysis of changes in biomass distribution}

The structure of Araucaria araucana trees changes with age, from a conical shape when young to an umbrella form when trees are older. Therefore, biomass distribution was divided into three age categories. The range of the categories was $<120$ years for group one, 120-240 years for group two and $>240$ years for group three. These age classes were used to split the data into three nearly equal sized groups, with 9 trees in group one and 12 each in group two and three.

\section{Software and source code}

Analyses were carried out in R ( $\mathrm{R}$ Core Team 2020). This included descriptive statistics using the $\mathrm{R}$ package "pastecs" (Grosjean 2018), one-way analysis of variance (ANOVA) using "multcomp" (Hothorn 2020), K-fold cross-validation using "caret" (Kuhn 2020), and visualizations with "ggplot2" (Wickham 2016). The R script used for multi-objective optimisation of biomass estimation models is available in Appendix 1 (Supplementary material).

\section{Results}

\section{Tree characteristics}

The estimation of basic density and moisture content at $0.3 \mathrm{~m}$ (diameter at stump height - DSH), $1.3 \mathrm{~m}$ (diameter at breast height - DBH), half of the total height and at the crown insertion revealed their variability along the stem profiles.

Basic density decreased from the base to the top and was higher in stem wood than in stem bark (Tab. 2). The variation detected at different positions in the stem profile was found to decrease from the stump to the top. In total, the weighted mean value of variation in basic density was up to $16.4 \%$ in stem wood and $21.4 \%$ in stem bark.

Moisture content along the stem profile, was found to increase from the stump to the top (Tab. 2), which is an opposite trend in comparison to basic density. The maximum variation in moisture content was $24.5 \%$ for stem wood and $29.4 \%$ for stem bark, both at the top of the tree (Tab. 2, Fig. 2). These increases in variation may also result from the fact that the values that are pooled to the relative stem profile positions originate from trees that repre-

\begin{tabular}{|c|c|c|c|c|c|c|c|}
\hline Variable & Component & Stats & Stump & DBH & Half & Crown & Total tree \\
\hline \multirow{6}{*}{$\begin{array}{l}\text { Basic density } \\
\left(\mathrm{Mg} \mathrm{m}^{-3}\right)\end{array}$} & \multirow[t]{3}{*}{ Wood } & Mean \pm SE & $0.595 \pm 0.0075$ & $0.579 \pm 0.0064$ & $0.484 \pm 0.0071$ & $0.497 \pm 0.0080$ & $0.539 \pm 0.0048$ \\
\hline & & Range & $0.667-0.472$ & $0.655-0.470$ & $0.581-0.413$ & $0.647-0.404$ & $0.602-0.461$ \\
\hline & & SD & 0.043 & 0.037 & 0.041 & 0.046 & 0.028 \\
\hline & \multirow[t]{3}{*}{ Bark } & Mean \pm SE & $0.363 \pm 0.0075$ & $0.358 \pm 0.0062$ & $0.328 \pm 0.0083$ & $0.285 \pm 0.0081$ & $0.334 \pm 0.0050$ \\
\hline & & Range & $0.430-0.239$ & $0.432-0.261$ & $0.456-0.247$ & $0.405-0.204$ & $0.384-0.276$ \\
\hline & & SD & 0.043 & 0.036 & 0.047 & 0.047 & 0.029 \\
\hline \multirow{6}{*}{$\begin{array}{l}\text { Moisture } \\
\text { content } \\
(\%)\end{array}$} & \multirow[t]{3}{*}{ Wood } & Mean \pm SE & $83.6 \pm 2.7$ & $83.0 \pm 3.2$ & $103.2 \pm 3.2$ & $110.8 \pm 4.1$ & $95.1 \pm 1.7$ \\
\hline & & Range & $150.5-59.5$ & $138.7-49.9$ & $150.1-58.2$ & $146.0-45.1$ & $113.4-76.6$ \\
\hline & & SD & 15.4 & 18.1 & 18.6 & 23.4 & 9.9 \\
\hline & \multirow[t]{3}{*}{ Bark } & Mean \pm SE & $123.0 \pm 3.3$ & $118.9 \pm 3.2$ & $135.7 \pm 5.2$ & $174.3 \pm 7.4$ & $138.0 \pm 3.4$ \\
\hline & & Range & $175.2-89.0$ & $157.2-78.3$ & $190.6-55.3$ & $279.3-94.1$ & $179.8-101.2$ \\
\hline & & SD & 18.7 & 18.5 & 29.8 & 42.4 & 19.6 \\
\hline
\end{tabular}
sent strongly varying absolute tree heights, which may therefore create more pronounced variations at the top than at the stump.

Strong differences in basic density and moisture content were also found between tree components (Tab. 3). They

Tab. 2 - Weighted mean and standard deviation (SD) values in basic density and moisture content at different stem positions. (SE): standard error. 
Fig. 2 - Basic density and moisture content in wood and bark ( $\left.\mathrm{Mg} \mathrm{m}^{-3}\right)$ at different positions through the stem profile. "a", "b" and "c" indicate significant $(P<0.05)$ differences between groups according to the Tukey test.
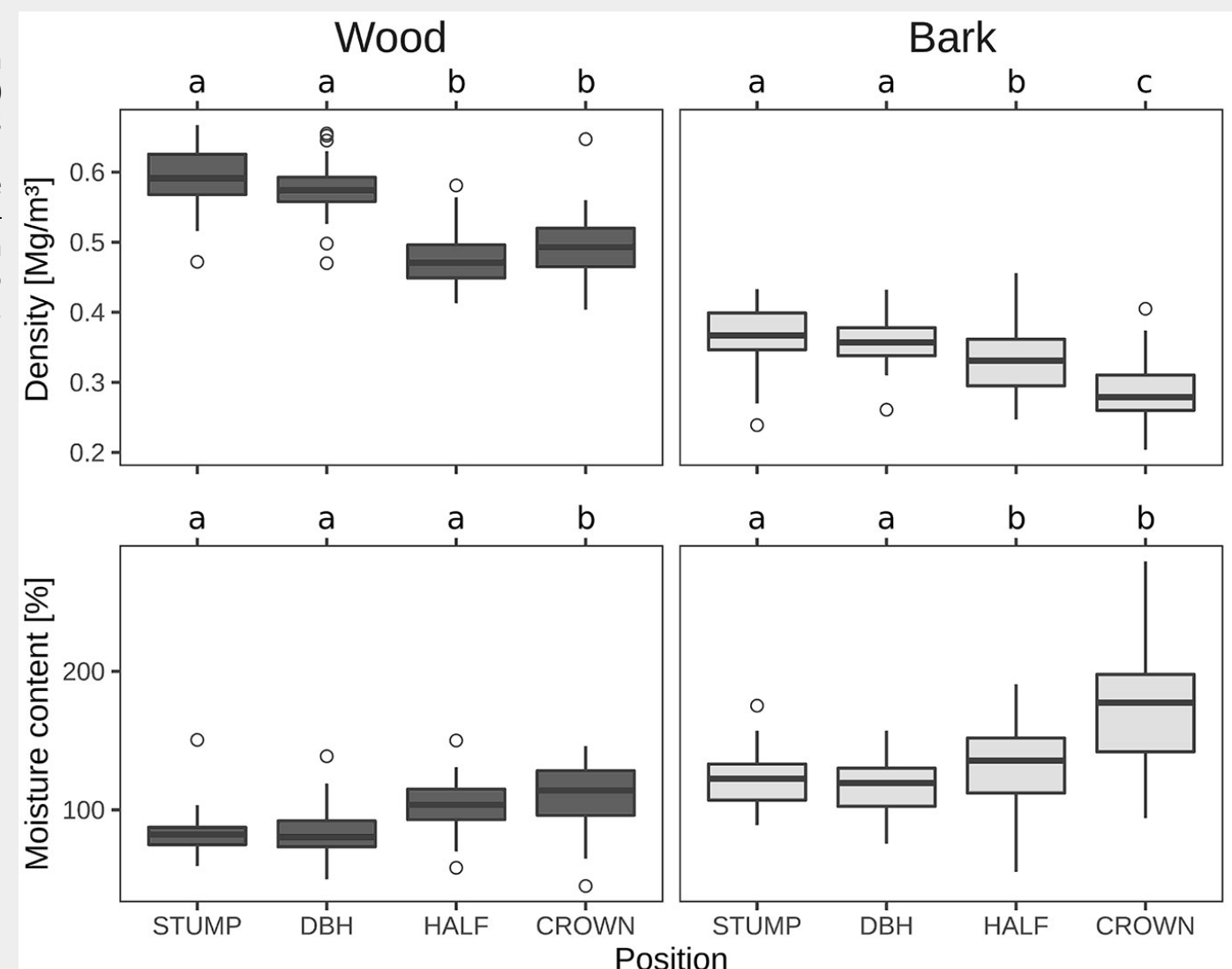

showed a tendency of wood > foliage > bark for mean estimates of basic density, with an opposite trend for moisture content (Fig. 3). The variability in basic density was much higher in foliage $(24 \%)$ than in wood $(6 \%)$ or bark $(10 \%)$, while the variability in moisture content was more similar (foliage: 9\%; bark: 16; wood: $11 \%$ ).

\section{Biomass estimation models}

We used multi-objective optimisation based on goodness-of-fit, cross-validation performance, and uncertainty of model parameters to identify the equations that best predicted total aboveground biomass as well as the biomass of stem wood, stem bark, and foliage. Models that did not take $\mathrm{DBH}$ into account and were only based on
Tab. 3 - Weighted mean \pm SD values of basic density and moisture content for the three tree components. (SE): standard error; (SD): standard deviation.

\begin{tabular}{lllc}
\hline $\begin{array}{l}\text { Tree } \\
\text { component }\end{array}$ & Stats & $\begin{array}{l}\text { Basic density } \\
\left(\mathrm{Mg} \mathrm{m}^{-3}\right)\end{array}$ & $\begin{array}{l}\text { Moisture content } \\
(\%)\end{array}$ \\
\hline Wood & Mean \pm SE & $0.518 \pm 0.0054$ & $98.3 \pm 1.9$ \\
\cline { 2 - 4 } & Range & $0.451-0.579$ & $73.7-123.9$ \\
\cline { 2 - 3 } & SD & 0.031 & 10.9 \\
\hline Bark & Mean \pm SE & $0.328 \pm 0.0059$ & $137.8 \pm 3.9$ \\
& Range & $0.257-0.410$ & $179.6-76.7$ \\
& SD & 0.034 & 22.4 \\
\hline \multirow{2}{*}{ Foliage } & Mean \pm SE & $0.431 \pm 0.0184$ & $114.3 \pm 1.8$ \\
& Range & $0.199-0.576$ & $83.6-137.3$ \\
& SD & 0.106 & 10.2 \\
\hline
\end{tabular}

Fig. 3 - Basic density (BD) and moisture content (MC) by tree components. "a', "b" and "c" indicate significant $(P<0.05)$ differences between groups according to the Tukey test.

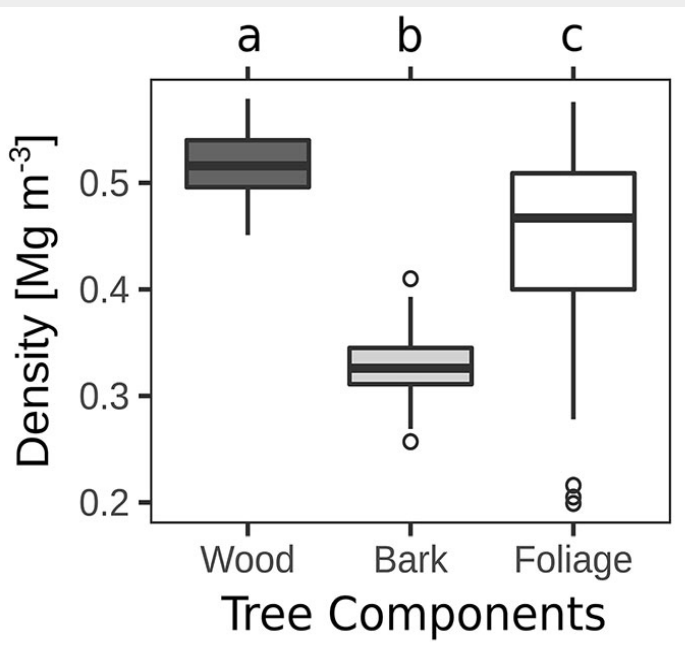

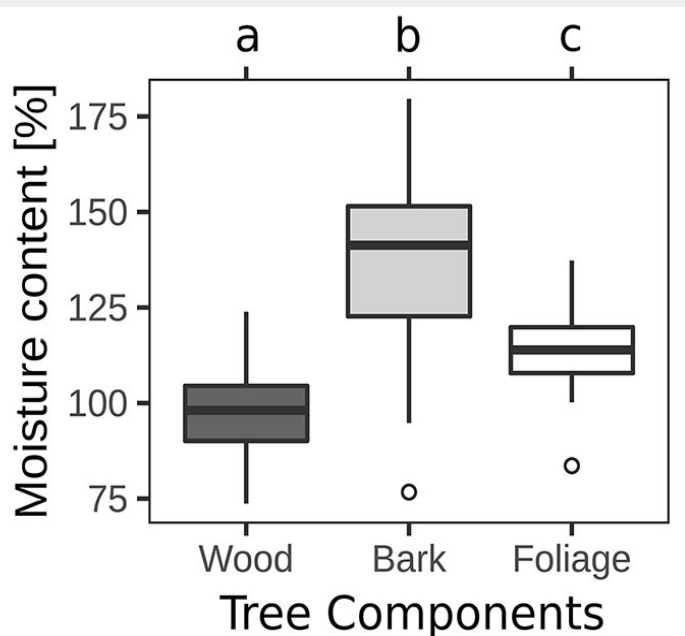


Tab. 4 - Best biomass estimation models found with multi-objective optimization. (TAGB): total aboveground biomass; (W): wood; (B): bark; (F): foliage; $\left(\beta_{0}, \beta_{1}, \beta_{2}, \beta_{3}\right)$ : model parameters estimated by ordinary least squares \pm their percent relative standard error, PRSE (\%); ( $\left.R^{2}\right)$ : Coefficient of determination; (RMSE): Root mean squared error; (MAPE): Mean absolute percentage error.

\begin{tabular}{|c|c|c|c|c|c|c|c|c|c|}
\hline Model & $\mathbf{Y}$ & $\boldsymbol{\beta}_{0}$ & $\boldsymbol{\beta}_{1}$ & $\boldsymbol{\beta}_{2}$ & $\boldsymbol{\beta}_{3}$ & $\mathbf{R}^{2}$ & $\begin{array}{c}\text { RMSE } \\
\text { (kg) }\end{array}$ & $\begin{array}{c}\text { MAPE } \\
\text { (\%) }\end{array}$ & $M A E \pm \sigma$ \\
\hline \multirow[t]{4}{*}{8} & TAGB & $-2.466 \pm 5.7$ & $2.437 \pm 1.5$ & - & - & 0.99 & 452.6 & 12.2 & $0.12 \pm 0.04$ \\
\hline & w & $-4.320 \pm 2.8$ & $2.709 \pm 1.2$ & - & - & 0.99 & 238.4 & 10.9 & $0.11 \pm 0.03$ \\
\hline & B & $-5.153 \pm 3.5$ & $2.585 \pm 1.8$ & - & - & 0.99 & 114.9 & 17.2 & $0.18 \pm 0.05$ \\
\hline & $\mathrm{F}$ & $-2.162 \pm 14.3$ & $2.118 \pm 3.8$ & - & - & 0.96 & 339.1 & 28.7 & $0.26 \pm 0.10$ \\
\hline \multirow[t]{4}{*}{9} & TAGB & $-1.995 \pm 13.2$ & $2.228 \pm 4.7$ & $0.022 \pm 48.2$ & - & 0.99 & 386.4 & 11.5 & $0.12 \pm 0.04$ \\
\hline & W & $-3.586 \pm 5.3$ & $2.385 \pm 3.2$ & $0.034 \pm 22.5$ & - & 0.99 & 152.3 & 8.5 & $0.09 \pm 0.03$ \\
\hline & $B$ & $-4.088 \pm 6.9$ & $2.114 \pm 5.4$ & $0.049 \pm 23.1$ & - & 0.99 & 77.1 & 12.5 & $0.13 \pm 0.04$ \\
\hline & $\mathrm{F}$ & $-2.519 \pm 24.4$ & $2.276 \pm 10.9$ & $-0.016 \pm 149.1$ & - & 0.96 & 335.8 & 28.6 & $0.27 \pm 0.11$ \\
\hline \multirow[t]{4}{*}{10} & TAGB & $-2.350 \pm 5.7$ & $2.354 \pm 1.9$ & $0.033 \pm 36.9$ & - & 0.99 & 337.4 & 10.4 & $0.11 \pm 0.04$ \\
\hline & W & $-4.264 \pm 3.0$ & $2.669 \pm 1.6$ & $0.016 \pm 71.9$ & - & 0.99 & 217.6 & 10.2 & $0.11 \pm 0.03$ \\
\hline & B & $-5.225 \pm 3.6$ & $2.637 \pm 2.4$ & $-0.020 \pm 83.4$ & - & 0.99 & 129.1 & 16.3 & $0.17 \pm 0.05$ \\
\hline & $\mathrm{F}$ & $-1.872 \pm 15.3$ & $1.909 \pm 5.0$ & $0.083 \pm 31.1$ & - & 0.97 & 345.5 & 25.1 & $0.26 \pm 0.08$ \\
\hline \multirow[t]{4}{*}{11} & TAGB & $-1.938 \pm 12.4$ & $2.173 \pm 4.5$ & $0.019 \pm 49.6$ & $0.031 \pm 37.8$ & 0.99 & 357.8 & 10.6 & $0.12 \pm 0.04$ \\
\hline & W & $-3.563 \pm 5.3$ & $2.363 \pm 3.3$ & $0.033 \pm 22.9$ & $0.012 \pm 74.3$ & 0.99 & 172.4 & 8.3 & $0.09 \pm 0.02$ \\
\hline & B & $-4.136 \pm 6.6$ & $2.161 \pm 5.2$ & $0.051 \pm 21.2$ & $-0.026 \pm 50.1$ & 0.99 & 91.2 & 12.2 & $0.14 \pm 0.04$ \\
\hline & $\mathrm{F}$ & $-2.361 \pm 22.7$ & $2.123 \pm 10.4$ & $-0.023 \pm 92.8$ & $0.086 \pm 30.2$ & 0.96 & 312.5 & 24.1 & $0.26 \pm 0.08$ \\
\hline \multirow[t]{4}{*}{12} & TAGB & $-2.062 \pm 8.5$ & $2.218 \pm 3.2$ & $0.035 \pm 32.6$ & $0.032 \pm 42.4$ & 0.99 & 303.4 & 9.8 & $0.11 \pm 0.04$ \\
\hline & w & $-4.045 \pm 4.2$ & $2.566 \pm 2.7$ & $0.017 \pm 63.9$ & $0.025 \pm 54.5$ & 0.99 & 254.0 & 10.1 & $0.11 \pm 0.03$ \\
\hline & B & $-4.948 \pm 5.2$ & $2.506 \pm 4.2$ & $-0.018 \pm 89.4$ & $0.031 \pm 65.1$ & 0.99 & 122.1 & 15.3 & $0.17 \pm 0.05$ \\
\hline & $\mathrm{F}$ & $-1.562 \pm 25.4$ & $1.763 \pm 9.2$ & $0.085 \pm 30.3$ & $0.035 \pm 89.4$ & 0.97 & 313.8 & 24.5 & $0.26 \pm 0.09$ \\
\hline
\end{tabular}

crown diameter $(C D)$, crown length $(C L)$, or dicted the biomass of individual tree com- the goodness-of-fit performance of the tree height (HT) did not fit the data very ponents were identified. However, they best models differs only slightly among well. Here, the five best equations found were not suitable for other tree compoare described (Tab. 4). These equations nents. Thus, the Pareto optimal solutions differed from the other models in combin- presented here are the covariate functions ing high quality of fit with relatively low un- that apply very well to all tree compocertainty of estimated model parameters nents. The comparison of measures such them. Prediction errors of $12.2 \%$ of the model based on DBH-only as an exploratory variable can be reduced to $9.8 \%$ when more covariates are used, but this improve(Fig. 4). Individual models that best pre- as $\mathrm{R}^{2}$, RMSE, MAPE, and MAE showed that in the percent relative standard error

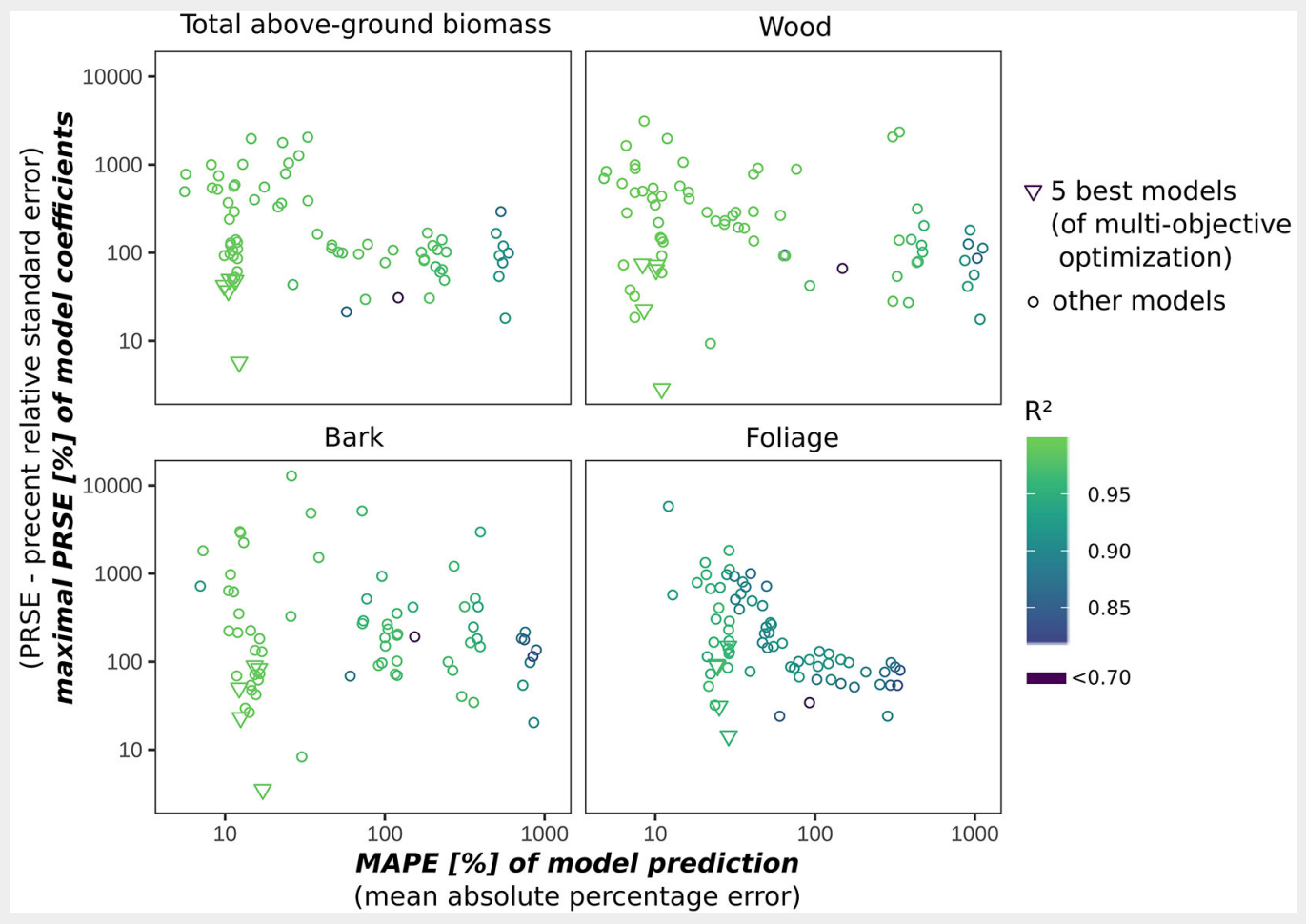

Fig. 4 - Pareto front showing the relationship between maximum percentage relative standard error of local model parameters and mean absolute percentage error of all local models tested. It confirms that the best five local models found by the applied multi-objective optimization approach are those that minimize these two critical estimates simultaneously for all four response variables. 
Fig. 5 - Biomass proportion for tree components in three groups of age (years).

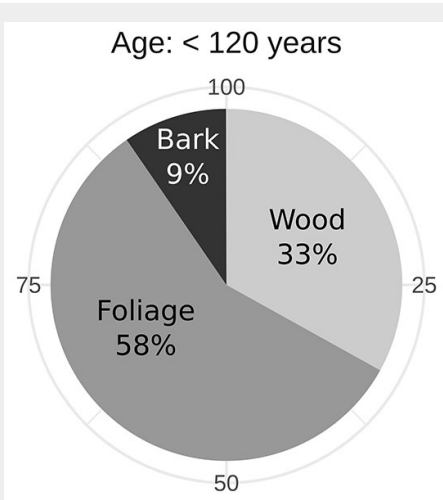

50

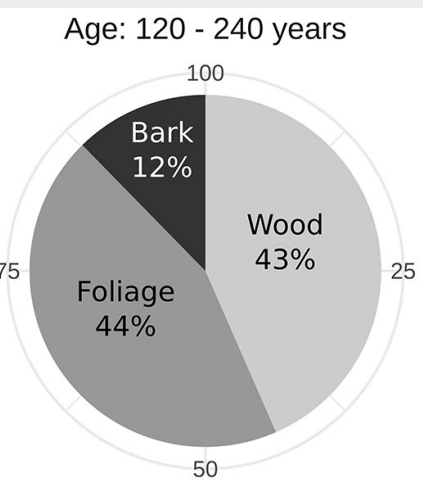

50

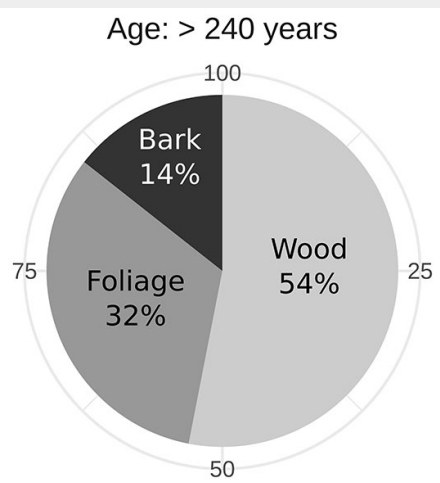

50

Biomass proportion [\%]

(PRSE) of estimated model coefficients. Whereas the DBH-only model has uncertainties in its estimation of model coefficients $<15 \%$, the PRSE is $>20 \%$ for tree height $(\mathrm{HT}),>30 \%$ for crown length (CL), and $>40 \%$ for crown diameter (CD). The model based on DBH and HT may be the best compromise for a modest error reduction with only a small increase in the maximum PRSE of the model coefficients. The strong relationship between observed and predicted values of model 9 is shown in Fig. S5 (Supplementary material). The $\mathrm{R}^{2}$ resulting from the $K$-fold cross validation was higher than 0.994 in all except the foliage component, where it ranged between 0.968 and 0.955 .

\section{Changes in biomass distribution}

The biomass proportion (\%) of stem wood and foliage changes with age in A. araucana (Fig. 5). The proportion of stem wood increases from relatively young trees to older trees. Conversely, the amount of foliage decreases as decreasing trees age. The proportion of stem bark was relatively stable and did not display marked differences among groups. In the three groups the distribution according to DBH was 10.0$29.1 \mathrm{~cm}$ (<120 years), $14.0-70.0 \mathrm{~cm}$ (120-240 years) and $48.8-126.4 \mathrm{~cm}$ ( $>240$ years).

\section{Discussion}

Cost-effective biomass equations are a crucial component of effective forest management. As a result, an essential first step is to identify equations that provide the greatest accuracy for a minimum of field investment. The study shows, despite its extremely distinctive habit, biomass in $A$. araucana scales predictably with size and age, meaning that it is entirely feasible to estimate biomass based on readily-measured variables. Our model selection process allows informed exclusion of some variables from field sampling protocols, including some that are time-consuming to measure. Part of this process involved identifying variables that do add predictive power but because the increase in prediction is relatively small, we recommend their exclusion from field surveys. In what follows, we explore these considerations for variable selection, as well as trends in biomass distribution that we identified in A. araucana.

\section{Identifying variables to measure in the} field to estimate biomass

Our multi-objective optimisation approach proved to be very informative regarding which variables to include and which not to include in field measurements for estimating $A$. araucana biomass. Our approach identified five models (sets of covariates) that minimised the errors and uncertainties in the prediction of total aboveground biomass and its components, which were stem wood, stem bark, and foliage (Tab. 4). We identified DBH and tree height $(\mathrm{HT})$, both very readily measured in the field, to be among the most important variables to be included in biomass estimation in our proposed local models. That the inclusion of HT can improve model quality has been previously reported in other species (Samuelson et al. 2014). Inclusion of height, though, does by no means always improve biomass estimations, as in tropical forests, where the poor performance of HT could be a consequence of the high variation in the relationship between tree height, crown area, and stem diameter, as well as an inconsistent relationship between age and tree size (Basuki et al. 2009). This variation underscores the need to explore models fits empirically on a case-by-case basis with procedures such as the one used here, which also identifies variables that can be excluded.

Our results suggest that including variables such as crown length, crown diameter, wood density, age, and basal area are not necessary for acceptable biomass predictions. Contrary to our expectations and to those of some previous authors (Wirth et al. 2004), the inclusion of crown length and crown diameter did not improve the accuracy of prediction of the foliage component (Tab. 4). It can therefore be concluded that crown measurements would incur unnecessary additional costs and that models based on DBH and HT, which have similar predictive capacities but more robust parameter estimates, are better suitable to predict total aboveground biomass as well as stem wood, stem bark and, foliage components of $A$. araucana. In some taxa, factors such as wood density have been found to be important (Chave et al. 2005, Basuki et al. 2009), whereas age was found to be important in others (Wirth et al. 2004). Here we found that wood density, age and, basal area did not improve biomass estimation, with the errors not substantially decreasing compared to the best models found, while the uncertainties increased, especially the percent relative standard error values of the estimated model parameters. Based on these results, these variables can be avoided in field sampling. Because wood density and especially age are quite time-consuming to measure, this finding substantially economizes field time. With regard to general models, it remains to be explored whether wood density, basal area, and age could improve general models that estimate forest biomass across wider geographical zones. With regard to local models of relevance to landowners, however, our results provide concrete guidance that biomass estimations can be quite confidently made including $\mathrm{DBH}$ and $\mathrm{HT}$, while age and basic density are not practical measurements in natural conditions for A. araucana. Our results also identified patterns of biomass distribution in A. araucana, which because of its distinctive habit we explore in detail now.

\section{Variation along the trunk and with tree} size

Our results show that wood density decreases and moisture content increases as a function of the stem height from stump to crown and were remarkably similar to other species (Fig. 2), even ones with habits very different from $A$. araucana. In $A$. angustifolia, one of the few other trees to share the umbrella-like habit of A. araucana, wood density also decreases acropetally (Curto et al. 2016). At $16.4 \%$, the vertical variation (stem wood) in A. araucana is higher compared to Pinus spp. (12\%) (Silva-Arredondo \& Návar-Cháidez 2012, Kimberley et al. 2015), but lower compared to Pinus massoniana Lamb. (37.9\%) (Deng et al. 2014), Picea sitchensis (Bong.) Carr. (20\%) (Dibdiakova \& Vadla 2012), and A. angusti- 
folia (28.3\%) (Curto et al. 2016). Moisture content increased vertically from the stump to the crown (Tab. 2), which can be explained by change in the proportion of sapwood (Longuetaud et al. 2017) in A. araucana. In contrast, there are species of Abies and Pinus that do not have a clear pattern (Goche-Télles et al. 2000). Other conifers, such as Picea sitchensis, have shown increases in moisture content of $42 \%$ along the stem (Dibdiakova \& Vadla 2012), which is much more pronounced comparing to $A$. araucana (24.5\%). These differences across species, even in the same genus, mean that variation in the distribution of basic density and moisture content base-to-top cannot simply be assumed and must be determined empirically, underscoring the need for data such as those presented here.

\section{Biomass distribution for tree}

\section{components in Araucaria araucana}

As with changes in density and moisture content with height, the distribution of biomass among trunk, branches, and foliage was also broadly like that found in other species, including those of similar and different habits. As in A. araucana, the proportion of wood increases over time (Fig. 5), while bark and foliage decreases in Pinus pinaster Aiton. (Porté et al. 2002). Along these lines, one study found that the proportion of wood increased from 66 to $83 \%$ in stands of $15-100$-year-old Pinus sylvestris $L$. trees, mirroring the trends found for A. araucana (Helmisaari et al. 2002). Similarly, foliage in Pinus strobus L. decreased from $52 \%$ to $33 \%$ in stands of $15-30$ year-old trees (Peichl \& Arain 2007). Moreover, our finding for the distribution of biomass in the youngest age class $(<120$ years) is similar to data of 29-33-year-old $A$. angustifolia trees, in the same genus (Sanguetta et al. 2003). Sanguetta et al. (2003) reported an allocation of $54.2 \%$ of the biomass to wood, $17.4 \%$ to bark and $27.9 \%$ to foliage, whereby that proportion was obtained from the sum of the subcomponents leaves (8.7\%), live branches (17.6\%) and dead branches (1.6\%). These values have also been confirmed by Schumacher et al. (2011), who reported on the distribution of wood (51.5\%), bark (14.7\%) and foliage $(18.9 \%)$ in a 27 -year-old stand of $A$. angustifolia, where the proportion of roots (13.0\%) was also determined. These results confirm the high proportion of the bark component in both Araucaria spp. (Fig. 5), compared to the $5.8 \%$ found in a plantation of 55-year-old Picea abies (L.) H. Karst. (Nihlgård 1972). According to Gayoso et al. (2002), these values are also higher compared to Pseudotsuga menziesii (Mirbel) Franco (8.3\%), Pinus ponderosa Douglas ex C. Lawson (6.6\%), and Pinus radiata D. Don (9.6\%). Understanding the distribution of biomass in Araucaria forest could explain some of the reasons for its survival in the face of so many natural disasters, such as forest fires and volcanic eruptions. It seems possible that these conditions of natural selection favor very thick bark in $A$. araucana as compared with other types of trees.

\section{Conclusions}

Our multi-objective optimisation identified local models that were characterised by low prediction errors and low uncertainties of model coefficients. The most important covariates for estimating total tree and components biomass were $\mathrm{DBH}$ and $\mathrm{HT}$, both readily measured in the field. Only the prediction of the foliage component was associated with higher errors, which could not be substantially reduced by including crown length and crown diameter. In $A$. araucana, basic wood and bark density decreased from the trunk base to the tip, whereas moisture increased. The observed values are in the middle and upper range of other conifers. The proportion of bark with respect to total biomass was found to be higher compared to most other conifers, although similar to A. angustifolia. Bark proportion also increases with age, as does the proportion of the tree stem biomass, while the proportion of foliage biomass decreases.

Our results have made an important contribution to the characterization of $A$. araucana, which is a remarkable species due to its unique architecture and its dominance across a wide range of high elevation woodlands. We believe that the approach presented here for the evaluation of biomass estimation models and its results guides future work in remote sensing, site productivity assessment and carbon stock quantification.

\section{List of abbreviations}

- CITES: Convention on International Trade in Endangered Species of Wild Fauna and Flora

- IUCN: International Union for Conservation of Nature

- UNFCCC: United Nation Framework Convention on Climate Change

- ISO: International Organization for Standardization

- AGRIMED: Centro de Agricultura y Medioambiente

\section{Acknowledgements}

EK, JG, MO, and MZ wrote the paper; MZ and EK performed the statistical analysis; $A B$ and JG carried out the field measurements; JG obtained the grant and designed the experiment; EK, MZ, PC, KD, JH and FP analysed data. All authors helped to improve the final version of the manuscript.

Our thanks to the Chilean National Forestry Corporation for the opportunity to conduct this study and for providing the authorisation of the felled trees. A special thank should also be given to the landowners who kindly donated the trees for this study. Our gratitude to Universidad Austral de Chile for supports for this research. We thank Christopher Marrs, who greatly im- proved the English version of this manuscript. Our gratitude to Dr. Victor Gerding, for his constant revisions, criticisms and suggestions to our manuscript, as well as to the anonymous reviewers who substantially improved the quality of our work. The corresponding author is supported by CONICYT Doctoral scholarship.

\section{References}

Aagesen D (1998). Indigenous resource rights and conservation of the Monkey-Puzzle tree (Araucaria araucana, Araucariaceae): a case study from Southern Chile. Economic Botany 52 (2): 146-160. - doi: 10.1007/BF02861203

Aagesen D (2004). Burning monkey-puzzle: native fire ecology and forest management in northern Patagonia. Agriculture and Human Values 21: 233-242. - doi: 10.1023/B:AHUM.00000 29402.85972.6C

AGRIMED (2017). Atlas agroclimático de Chile. Estado actual y tendencias del clima. Tomo IV: Regiones del Biobío y de La Araucanía [Agroclimatic atlas of Chile. Current status and climate trends. Volume VI: Regions of Biobio and Araucania]. Universidad de Chile y Centro de Agricultura y Medioambiente. Santiago, Chile, pp. 136. [in Spanish]

Antony F, Schimleck LR, Daniels RF (2012). Identification of representative sampling heights for specific gravity and moisture content in plantation-grown loblolly pine (Pinus taeda). Canadian Journal of Forest Research 42: 574-584. - doi: 10.1139/X2012-009

Basuki TM, Van Laake PE, Skidmore AK, Hussin YA (2009). Allometric equations for estimating the above-ground biomass in tropical lowland Dipterocarp forests. Forest Ecology and Management 257: 1684-1694. - doi: 10.1016/j.foreco. 2009.01.027

Beets PN, Kimberley MO, Oliver GR, Pearce SH, Graham JD, Brandon A (2012). Allometric equations for estimating carbon stocks in natural forest in New Zealand. Forests 3: 818-839. - doi: 10.3390/f3030818

Beets PN, Garrett LG (2018). Carbon fraction of Pinus radiata biomass components within New Zealand. New Zealand Journal of Forestry Science 48: 14. - doi: 10.1186/s40490-018-0119-5

Chave J, Andalo C, Brown S, Cairns MA, Chambers JQ, Eamus D, Fölster H, Fromard F, Higuchi $\mathrm{N}$, Kira T, Lescure JP, Nelson BW, Ogawa $\mathrm{H}$, Puig H, Riéra B, Yamakura T (2005). Tree allometry and improved estimation of carbon stocks and balance in tropical forests. Oecologia 145: 87-99. - doi: 10.1007/s00442-005-0100-x

Curto RA, Povoa De Mattos P, Muñoz Braz E, Netto SP, Zachow R (2016). Density of Araucaria angustifolia wood from overstocked stand. Brazilian Journal of Forestry Research 36 (85): 51-59. - doi: 10.4336/2016.pfb.36.85.963 Cutini A, Chianucci F, Manetti MC (2013). Allometric relationships for volume and biomass for stone pine (Pinus pinea L.) in Italian coastal stands. iForest - Biogeosciences and Forestry 6: 331-337. - doi: 10.3832/iforo941-006 Deng X, Zhang L, Lei P, Xiang W, Yan W (2014). Variations of wood basic density with tree age and social classes in the axial direction within Pinus massoniana stems in Southern China. Annals of Forest Science 71: 505-516. - doi: 10.1007/ 
s13595-013-0356-y

Dibdiakova J, Vadla K (2012). Basic density and moisture content of coniferous branches and wood in Northern Norway. EPJ Web of Conferences 33: 1-6. - doi: 10.1051/epjconf/20123302005 Donoso C (2006). Las especies arbóreas de los bosques templados de Chile y Argentina: autoecología [Tree species from the temperate forests of Chile and Argentina: autoecology]. Marisa Cuneo Ediciones, Valdivia, Chile, pp. 678. [in Spanish]

Donoso SR, Peña-Rojas K, Espinoza C, Galdames E, Pacheco C (2014). Producción, permanencia y germinación de semillas de Araucaria araucana (Mol.) K. Koch en bosques naturales, aprovechados por comunidades indígenas del sur de Chile [Production, permanence and germination of seeds of Araucaria araucana (Mol.) K. Koch in natural forests, used by indigenous communities in southern Chile]. Interciencia 39 (5): 338-343. [in Spanish] [online] URL: http:// repositorio.uchile.cl/handle/2250/166175

Fayolle A, Doucet JL, Gillet JF, Bourland N, Lejeune $P$ (2013). Tree allometry in Central Africa: testing the validity of pantropical multi-species allometric equations for estimating biomass and carbon stocks. Forest Ecology and Management 305: 29-37. - doi: 10.1016/j.foreco.2013. 05.036

Gayoso J, Guerra J, Alarcón D (2002). Contenido de carbono y funciones de biomasa en especies nativas y exóticas. Medición de la capacidad de captura de carbono en bosques de Chile y promoción en el mercado mundial [Carbon content and biomass functions in native and exotic species. Measurement of carbon sequestration capacity in Chilean forests and promotion in the world market]. Technical report FONDEF D9811076, Instituto Forestal y Universidad Austral de Chile, Valdivia, Chile, pp. 53. [in Spanish] Gayoso J (2013). Funciones alométricas para la determinación de existencias de carbono forestal para la especie Araucaria araucana (Molina) K. Koch (ARAUCARIA) [Allometric functions for the determination of forest carbon stocks for the species Araucaria araucana (Molina) K. Koch (ARAUCARIA)]. Ministerio de Agricultura, Corporación Nacional Forestal. Santiago, Chile, pp. 49. [in Spanish]

Goche-Télles JR, Fuentes-Salinas M, Borja-De la Rosa A, Ramírez-Maldonado H (2000). Variación de las propiedades físicas de la madera en un árbol de Abies religiosa y de Pinus ayacahuite var. veitchii [Variation in physical properties of Abies religiosa and Pinus ayacahuite var. veitchii wood]. Revista Chapingo - Serie Ciencias Forestales y del Ambiente 6 (1): 83-92. [in Spanish] [online] URL: http://www.researchgate.net/pu blication/266407307

González-Benecke CA, Gezan SA, Albaugh TJ, Lee Allen $H$, Burkhart HE, Fox TR, Jokela EJ, Maier CA, Martin TA, Rubilar RA, Samuelson LJ (2014). Local and general above-stump biomass functions for loblolly pine and slash pine trees. Forest Ecology and Management 334: 254-276. - doi: 10.1016/j.foreco.2014.09.002

Goulding CJ (1979). Cubic spline curves and calculation of volume of sectionally measured trees. New Zealand Journal of Forestry Science 9 (1): 89-99. - [online] URL: http://citeseerx.ist. psu.edu/viewdoc/download?doi=10.1.1.710.5351 \&rep=rep1\&type=pdf

Grosjean P (2018). Pastecs: analysis of spacetime ecological series. $R$ package version 1:3.21. [online] URL: http://cran.r-project.org/web/pac kages/pastecs/

Hastie T, Tibshirani T, Friedman J (2017). The elements of statistical learning: data mining, inference and prediction ( $2^{\text {nd }}$ edn). Springer, New York, USA, pp. 763.

Helmisaari HS, Makkonen K, Kellomäki S, Valtonen E, Mälkönen E (2002). Below- and aboveground biomass, production and nitrogen use in Scots pine stands in eastern Finland. Forest Ecology and Management 165: 317-326. - doi: 10.1016/S0378-1127(01)00648-X

Hothorn T (2020). Multcomp: simultaneous inference in general parametric models. R package version 1:4-12. [online] URL: http://cran.rproject.org/web/packages/multcomp/

ISO-13061-1 (2014). Physical and mechanical properties of wood - Test methods for small clear wood specimens - Part 1: Determination of moisture content for physical and mechanical tests. International Organization for Standardization, Geneva, Switzerland, pp. 4.

ISO-13061-2 (2014). Physical and mechanical properties of wood - Test methods for small clear wood specimens - Part 2: Determination of density for physical and mechanical tests. International Organization for Standardization, Geneva, Switzerland, pp. 5.

Kimberley MO, Cown DJ, McKinley RB, Moore $J R$, Dowling $L J$ (2015). Modelling variation in wood density within and among trees in stands of New Zealand-grown radiata pine. New Zealand Journal of Forestry Science 45: 22. - doi: 10.1186/s40490-015-0053-8

Kizha AR, Han HS (2016). Predicting aboveground biomass in second growth coast redwood: comparing localized with generic allometric models. Forests 7 (12): 96. - doi: 10.3390/ f7050096

Kuhn M (2020). Caret: classification and regression training. $R$ package version 6:0-85. [online] URL: http://CRAN.R-project.org/package=caret Longuetaud F, Mothe F, Santenoise P, Diop N, Dlouha J, Fournier M, Deleuze C (2017). Patterns of within-stem variations in wood specific gravity and water content for five temperate tree species. Annals of Forest Science 74: 64. doi: 10.1007/s13595-017-0657-7

Nihlgård B (1972). Plant biomass, primary production and distribution of chemical elements in a beech and a planted spruce forest in South Sweden. Oikos 23: 69-81. - doi: 10.2307/3543928 Payandeh B (1981). Choosing regression models for biomass prediction equations. The Forestry Chronicle 57 (5): 229-232. - doi: 10.5558/tfC5722 9-5

Peichl M, Arain MA (2007). Allometry and partitioning of above- and belowground tree biomass in an age-sequence of white pine forests. Forest Ecology and Management 253: 68-80. doi: 10.1016/j.foreco.2007.07.003

Premoli A, Quiroga P, Gardner M (2013). Araucaria araucana. The IUCN red list of threatened species, the World Conservation Union, Gland, Switzerland, pp. 10. - doi: 10.2305/IUCN.UK.201 3-1.RLTS.T31355A2805113.en

Porté A, Trichet P, Bert D, Loustau D (2002). Allometric relationships for branch and tree woody biomass of Maritime pine (Pinus pinaster Ait.). Forest Ecology and Management 158: 71-83. doi: 10.1016/S0378-1127(00)00673-3

R Core Team (2020). R: a language and environment for statistical computing, version 3.5.1. The R Project for Statistical Computing, Vienna, Austria. [online] URL: http://www.r-project.org/ Samuelson LJ, Stokes TA, Butnor JR, Johnsen KH, González-Benecke CA, Anderson P, Jackson J, Ferrari L, Martin TA, Cropper Jr WP (2014). Ecosystem carbon stocks in Pinus palustris forests. Canadian Journal of Forest Research 44: 476-486. - doi: 10.1139/cjfr-2013-0446

Sanguetta CR, Watzlawick LF, Schumacher MV, De Mello AA (2003). Relações individuais de biomassa e conteúdo de carbono em plantações de Araucaria angustifolia e Pinus taeda no sul do estado do Paraná, Brasil [Individual biomass and carbon content in Araucaria angustifolia and Pinus taeda plantations in southern Parana state, Brazil]. Revista Acadêmica: Ciências Agrárias e Ambientais 1 (3): 33-40. [in Portuguese] - doi: 10.7213/cienciaanimal.v1i3.14 937

Schmidt H (1977). Dinámica de un bosque virgen de Araucaria - Lenga (Chile) [Dynamics of a virgin forest in Araucaria-Lenga (Chile)]. Bosque 2 (1): 3-11. [in Spanish] - doi: 10.4206/bosque.19 77.v2n1-02

Schumacher MV, Witschoreck R, Calil FN, Lopes VG, Viera $M$ (2011). Produção de biomassa no corte raso em plantio de Araucaria angustifolia (Bertol.) Kuntze de 27 anos de idade em quedas do Iguaçu, PR [Biomass production after clear cutting in a 27-year-old stand of Araucaria angustifolia (Bertol.) Kuntze at Iguaçu waterfalls, PR]. Ciência Florestal 21 (1): 53-62. [in Portuguese] - doi: 10.5902/198050982747

Sileshi GW (2014). A critical review of forest biomass estimation models, common mistakes and corrective measures. Forest Ecology and Management 329: 237-254. - doi: 10.1016/j.for eco.2014.06.026

Silva-Arredondo FM, Návar-Cháidez JJ (2012). Estimación de la densidad de madera en árboles de comunidades forestales templadas del norte del estado de Durango, México [Estimating bole wood specific gravity in trees of temperate forest communities of northern Durango, Mexico]. Madera y Bosques 18 (1): 77-88. [in Spanish] - doi: 10.21829/myb.2012.1811139

Wickham H (2016). ggplot2: elegant graphics for data analysis. Springer-Verlag, New York, USA, pp. 213.

Wirth C, Schumacher J, Schulze ED (2004). Generic biomass functions for Norway spruce in Central Europe - a meta-analysis approach toward prediction and uncertainty estimation. Tree Physiology 24: 121-139. - doi: 10.1093/tree phys/24.2.121 


\section{Supplementary Material}

Fig. S1 - Destructive sampling, including all measurements before and after felling trees (left) and samples taken to determine basic density and moisture content at different stem positions (right).
Fig. S2 - Foliage component. Representation of foliage component, which includes branches and scaly, leathery leaves as a whole component.

Fig. S3 - Scatter graph for the relation of aboveground biomass ( $\mathrm{kg}$ tree ${ }^{-1}$ ) to $\mathrm{DBH}$ (cm): (A) whole tree, (B) stem wood, (C) stem bark and (D) foliage.
Fig. S4 - Model prediction in the equation 9 using predicted versus observed values for tree components and total aboveground biomass.

Appendix 1 - R-Script for multi-objective model comparison.

Link: Kutchartt_3492@supplo01.pdf 